\title{
Tracking Double-up Food Bucks (DUFB) Program Use Among Supplemental Nutrition Assistant Program (SNAP) Recipients and the Implications for Healthy Food Access
}

\section{Abiodun T. Atoloye and Carrie Durward ${ }^{2}$}

\author{
Affiliation of Authors: \\ ${ }^{1}$ Rudd Center for Food Policy and Obesity \\ University of Connecticut, Storrs, CT, USA \\ ${ }^{2}$ Department of Nutrition, Dietetics and Food Science \\ Utah State University, Logan, UT, USA
}

\begin{abstract}
Summary
Acceptance of SNAP benefits has increased in farmers' markets (FM) over the years. However, getting SNAP recipients to take up the opportunity of extra dollars for healthy food options remains a challenge. Thus, we tracked the use of the Double-up Food Buck (DUFB) program among SNAP recipients who visit participating FMs in Utah to understand the unique characteristics of the program users. Our results identified varying types of program users (multiple and single market shoppers, more frequent and less frequent shoppers). While our findings indicate a higher DUFB transaction in token value among frequent users, larger markets are more likely to have higher DUFB transactions with a higher number of market visits compared to smaller ones. In conclusion, while all types of users may add to the total revenue generated by participating FM, additional initiatives are required to encourage frequent visits and uptake of the program for better access to healthy foods.
\end{abstract}

Keywords: Farmers' market, Incentive program, SNAP benefits, Double-up Food Buck, Incentive tracking system

\section{Corresponding Author:}

Abiodun T. Atoloye, $\mathrm{PhD}$

abiodun.atoloye@uconn.edu

Rudd Center for Food Policy and Obesity

One Constitution Plaza, Suite 6, Hartford

University of Connecticut, USA 
List of Figures.

Table of Contents

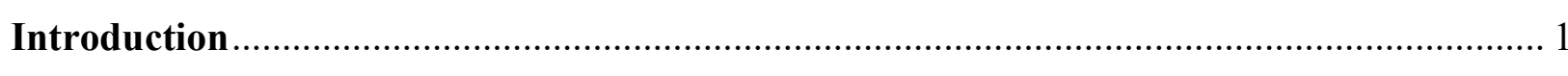

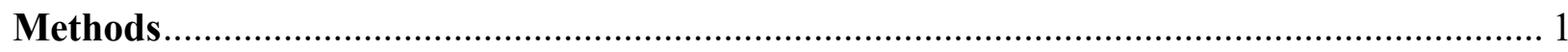

Compliance to Tracking System and Data Analysis .................................................. 1

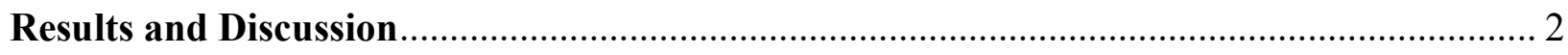

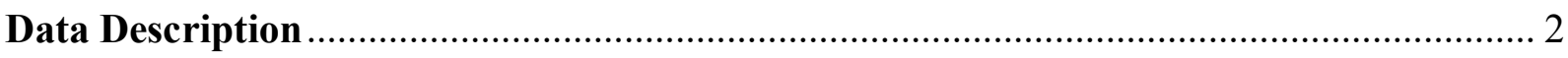

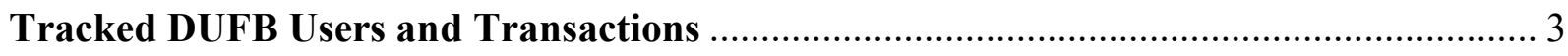

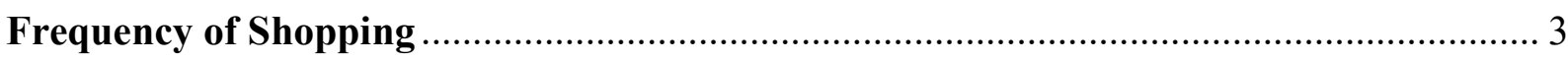

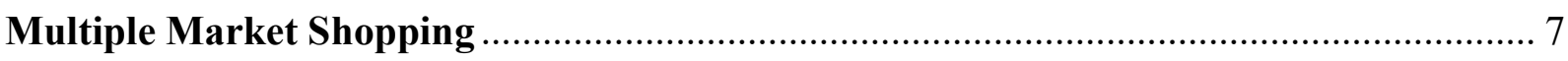

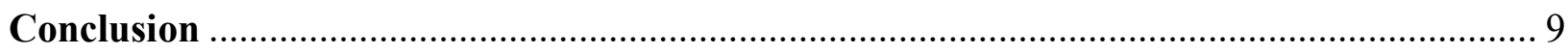

Recommendations for Policy, Practice, and Research ..................................................... 9

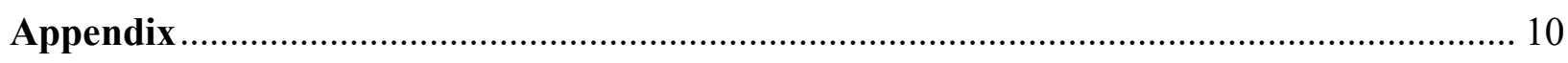

Appendix A. Categories of the Different Entries ....................................................... 10

Appendix B. Sticker Record-keeping and Entries Associated with a Unique Individual Sticker (Tracked) across the Different Markets.......................................................... 11

Appendix C: Total DUFB per Market Versus Tracked DUFB Users........................... 12

Appendix D: Frequency Of Farmer's Market Visit Versus Number of Individuals ........ 12

Appendix E: Number of Weeks of DUFB Possible and Recorded Per Market................ 13

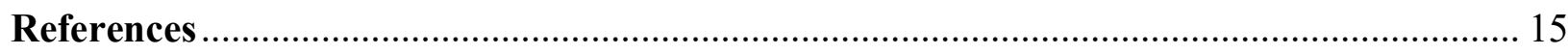

List of Figures 
Figure 1: Frequencies of Shopping Versus DUFB Tokens Distributed Over the Market

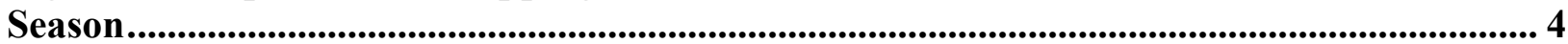

Figure 2: Frequencies of Shopping Versus Amount of SNAP Distributed Over the Market

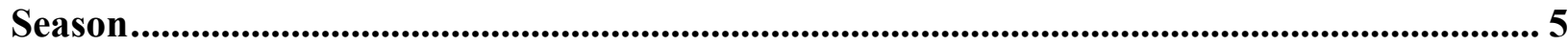

Figure 3. Amount of DUFB Distributed Per Frequency of Shopping in Each Market......... 6

Figure 4. Amount of SNAP Distributed Per Frequency of Shopping in Each Market .......... 7

Figure 5. Number of Multiple Market Shoppers between Markets 


\section{Introduction}

Double-up Food Bucks, DUFB is a fruit and vegetable (FV) incentivize program designed to improve the dietary quality of low-income populations through the Supplemental Nutrition Assistance Program (SNAP). Prior studies have shown that DUFB program has positive effects on the F\&V purchase behavior (such as expenditure share, variety purchased, frequency, and amount of F\&V purchase) (Steele-Adjognon \& Weatherspoon, 2017; Alaofè, Freed, Jones, Plano, \& Taren, 2017) and consumption (such as number of F\&V consumed) (Savoie-Roskos, Durward, Jeweks, \& LeBlanc, 2016; Alaofè et al., 2017; Durward et al., 2018). Nevertheless, DUFB use tends to be less common among SNAP recipients with initial low FV intake, who do not have previous experience shopping at a farmers' market with their SNAP benefit, and who have lesser income (author's data currently in publication, available on request).

Given the potential benefit of this program, the question of how to get these different subgroups within the target population attracted to this SNAP-based incentive program remains. Further evaluation of the usage of the incentive program will provide insight on how to best target the intended population. This report explored the utility of DUFB by SNAP recipient at farmers' market and provided the estimate of numbers of unique program users in Utah State.

\section{Methods}

To estimate the number of the unique user of the program, we used a sticker number system to track DUFB transactions among SNAP recipients who visited a participating farmers' markets (FM) in the 2018 FM season. 15 DUFB participating FMs were included in the study and all DUFB sticker numbers issued to participating FMs were between 1-3000; each market received a distinct range of sticker numbers. Prior to the beginning of the FM season, market managers were asked to adopt the tracking system for the 2018 FM season and were also provided with instructions on how to use the tracking resources. At the beginning of the FM season, all farmers' market shoppers (SNAP recipients) who approach the information desk were asked if he or she was interested in getting a colored (green), numbered sticker on their Electronic Benefit Transfer (EBT) card. A green sticker was placed on the EBT card (in a way that the sticker does not cover the magnetic strip or the card number) of any shopper who showed interest, and this was used to track all transactions made by the individual shopper throughout the FM season. Starting with the first transaction where a green sticker was issued, all subsequent transactions (SNAP dollar spent and DUFB token distributed) of an individual shopper with a green sticker at any of the participating markets were recorded by the vendor against their sticker number. On every FM operation hours/day during the 2018 FM season, any SNAP shoppers who had no sticker on his or her EBT card was asked if he or she will like to have one and their transactions were recorded. At the end of the FM season, the transaction records of all shoppers in each market were collated and the total transaction for the season from each participating market was collated.

\section{Compliance to Tracking System and Data Analysis}

During data processing, we assessed compliance to the tracking system and found that there were instances where vendors recorded the last 4 digits of the shopper's EBT card instead of the green 
sticker number, which was part of the reporting from the previous year. Besides mis-recording, we also identified additional instances where compliance with the tracking system was not $100 \%$.

To process the data for analysis, the first step was to identify the numbers that were actual DUFB sticker numbers. We set the following rules to guide the data sorting:

- Identifying and separating numbers that were below 3000.

- Identifying numbers that were below 3000 which occur in sequential order within records from a specific market (these assisted the identification of the range of DUFB sticker numbers within each market). We also checked for numbers above 3000 that were on each market day's record sheet; we decided a vendor was using the last-4 digit of the EBT card for the day if there are numbers above 3000 on each day's record sheets. Hence, those numbers below 3000 that do not appear to match numbers with a market's assigned range or on a record sheet classified to report last- 4 digit of EBT card were categorized as non-DUFB sticker numbers.

- Identifying sticker numbers that are within a specific market's assigned range but also appeared in another market (these were regarded as multiple market users).

- Other transactions by those who refused stickers, customers from outside Utah, numbers that occurred in multiple markets but the date of first use does not align with the market first issued that range, numbers that have no replicate in markets that were assigned that range, and some without any recorded numbers were also removed from DUFB sticker number category.

We then used descriptive analyses such as percentage, frequency, etc. to explore the unique characteristics of the individual program users whose transaction could be tracked using the sticker system (classified as a tracked individual) and generated some hypothesis for further research.

\section{Data Description}

\section{Results and Discussion}

Appendix A shows the categories of the different entries based on the method used for sorting the data. Of the 1567 SNAP/DUFB transaction entries, 1040 (66.4\%) entries were associated with a tracked individual. If we look at the dollar amount of DUFB benefits distributed, $67.7 \%$ of the total amount was associated with an individual in our sticker tracking system ( $\$ 9441$ out of $\left.\$ 13942.5^{1}\right)$. A similar percentage of SNAP transactions were associated with a number in the sticker system $(68.9 \%, \$ 15637.11$ out of $\$ 22698.41)$.

Appendix B shows the sticker record-keeping compliance rate by markets. Entries from 3 markets (Benson, Syracuse, and Brigham) could not be included as part of the tracked DUFB transactions. These results show that we did not get perfect compliance with sticker recordkeeping across the participating markets. This may be due to poor communication between the market manager and the vendors or inadequate follow-up strategies by the program manager. Future studies should identify effective strategies that include adequate follow-up and monitoring of data collection to increase compliance across all participating FM.

\footnotetext{
${ }^{1}$ Syracuse Farmer's Market reported one transaction of $\$ 7.50$.
} 


\section{Tracked DUFB Users and Transactions}

Across all markets, there were a total of 592 tracked DUFB users. Of these, 13 shopped at multiple markets, so there were 562 tracked unique individuals. Larger markets (as described by the total SNAP transaction, number of vendors, and market capacity) had a higher number of DUFB users, a higher amount of DUFB, and SNAP transactions. Similarly, Appendix B shows that the percentage of tracked DUFB transactions was higher in larger markets (e.g. Ogden, Salt Lake City, and Cache FMs) compare to smaller markets. Appendix C presents a graph of the number of individuals tracked per market against the amount of tracked DUFB token and this shows a similar trend among larger markets compared to smaller markets (i.e. there was a higher number of tracked individual with higher DUFB token distributed). This also indicates that larger markets did a better job of adhering to the tracking system.

\section{Frequency of Shopping}

The maximum number of times that tracked shoppers made transactions during the FM season was 14 times and the minimum was once as shown in Appendix D. The data distribution in Figure 1 shows that customers who came to the market more frequently received a larger number of matched tokens from the DUFB program over the market season. This makes intuitive sense since shoppers are limited to $\$ 10$ in tokens per market visit. On the other hand, we did not see a strong relationship (see Figure 2) between the number of market visits and the amount of SNAP distributed. In other words, there are individuals who visited only a few times but received a total SNAP in dollar value that is comparable to the amount spent by those who shopped many times. This difference in the trends is not surprising because the amount of matching DUFB tokens per visit was capped while the amount of SNAP spendable per visit was not limited in the same way. These results should be considered when planning for future years. Future planning should consider if the program goals align with encouraging shopping at the market each week or maximizing benefits for all FM customers when considering the amount of allowed match per visit. 
Figure 1: Frequencies of Shopping Versus DUFB Tokens Distributed Over the Market Season

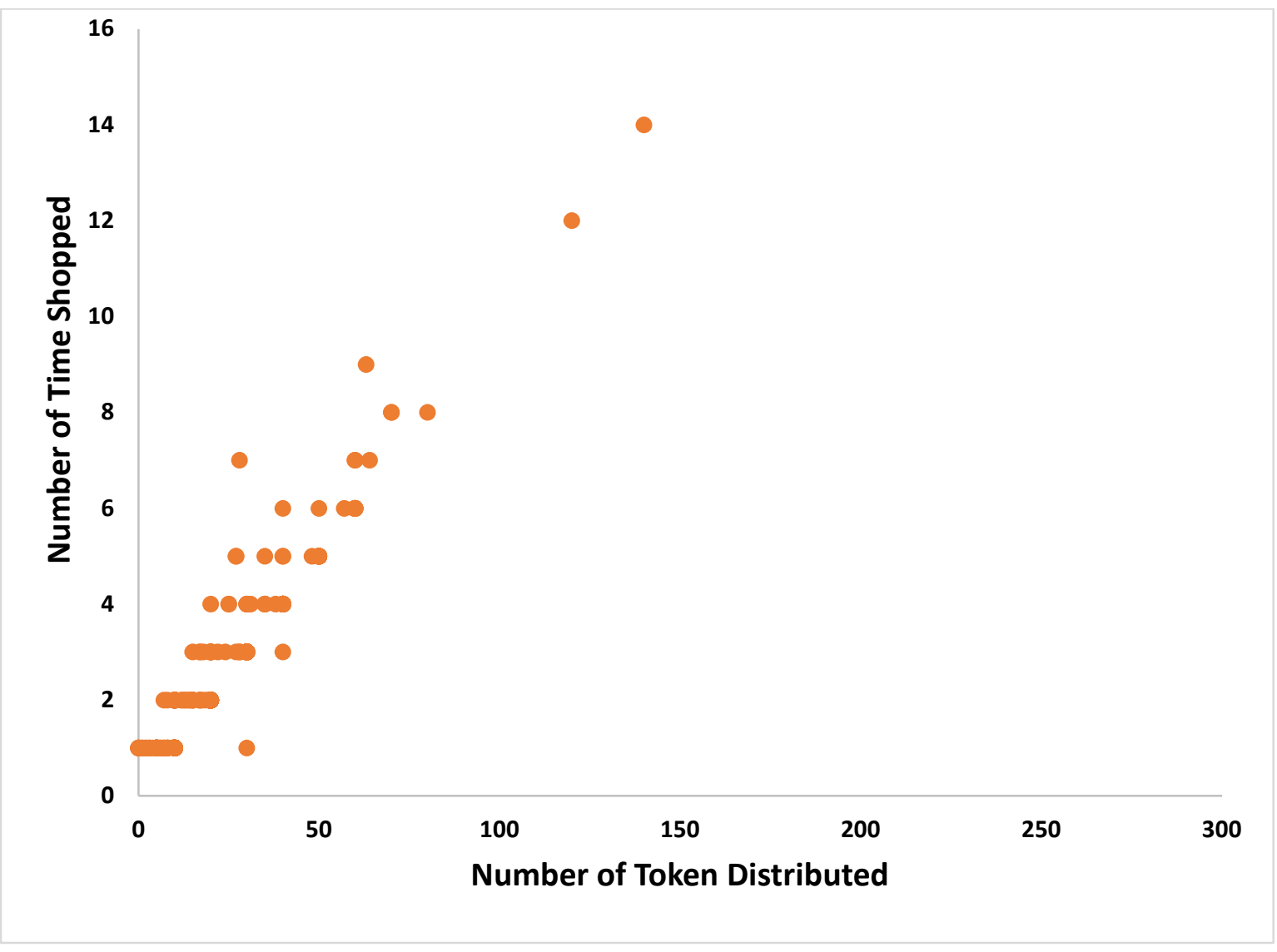


Figure 2: Frequencies of Shopping Versus Amount of SNAP Distributed Over the Market Season

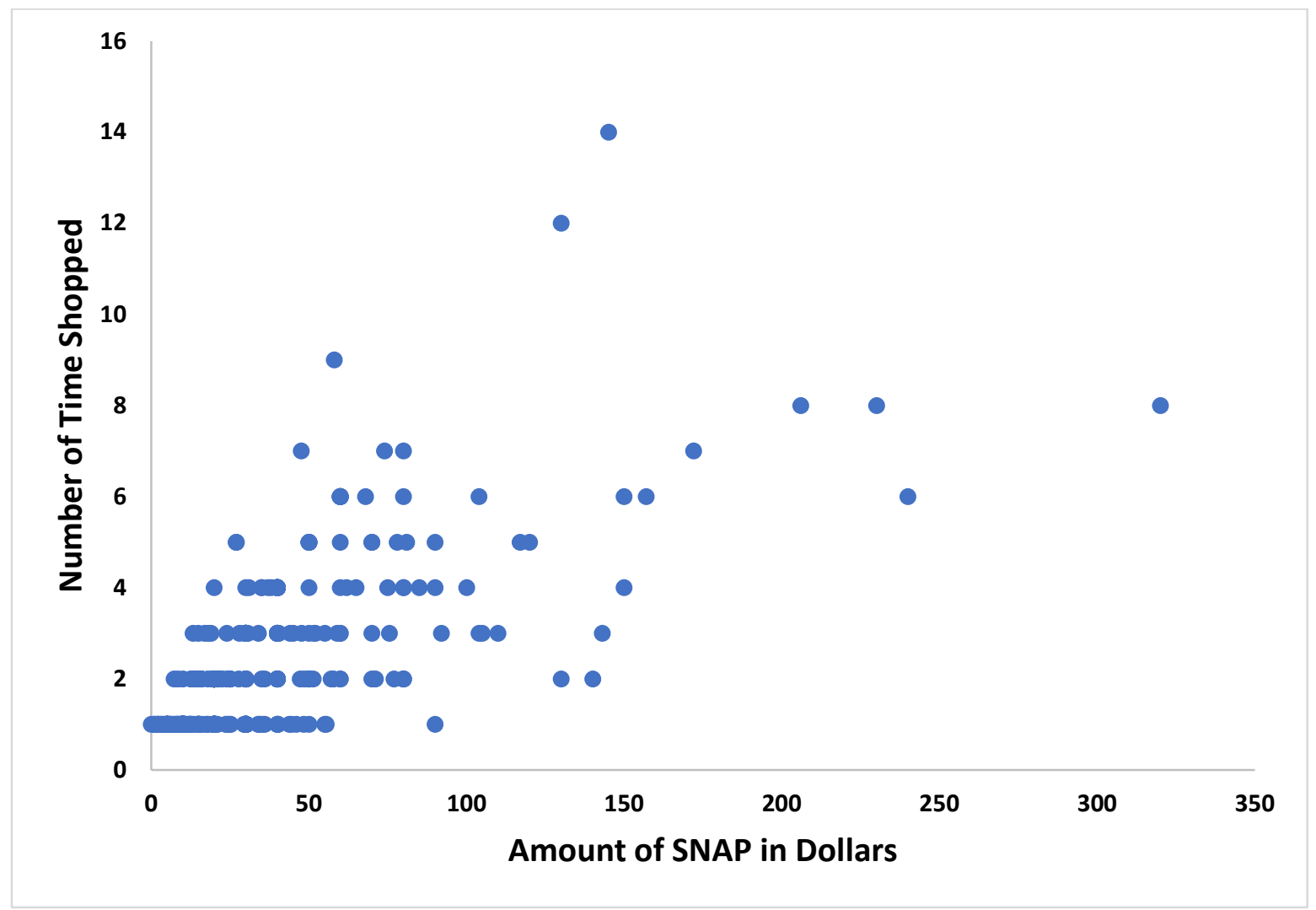

The amount of DUFB and SNAP distributed by the frequency of shopping vary across the different markets. Figures 3 and 4 showed that smaller markets have a similar trend for DUFB and SNAP transactions irrespective of the number of times FM was visited while bigger markets have a higher amount of SNAP and DUFB distributed among individuals who shopped fewer times compared to those who shopped many times. It may be that larger markets have a higher number of individuals who shop only a few times but whose transaction added up to give a high total transaction for the FM season. Also, it is important to note that markets were not opened for the same number of weeks (see Appendix E), this indicates that there is a limit to the frequency of visits that could possibly be made by DUFB users at some FM. Smaller markets like Summit FM and Syracuse were opened for a lesser number of weeks compared to larger markets and this may also be responsible for the relationship observed between frequency of shopping and amount of SNAP and DUFB distributed in such smaller markets. 
Figure 3. Amount of DUFB Distributed Per Frequency of Shopping in each Market

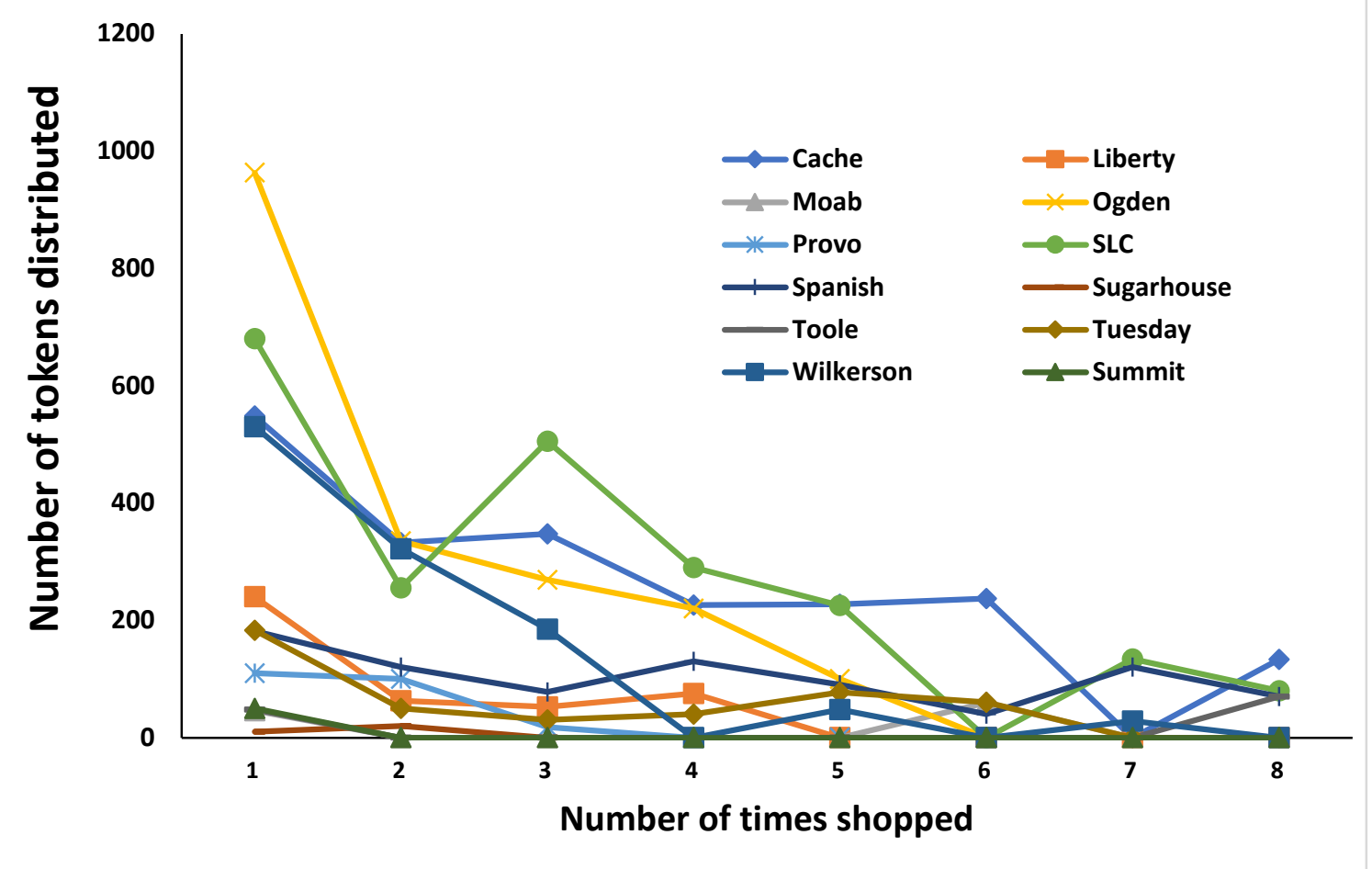


Figure 4. Amount of SNAP Distributed Per Frequency of Shopping in Each Market

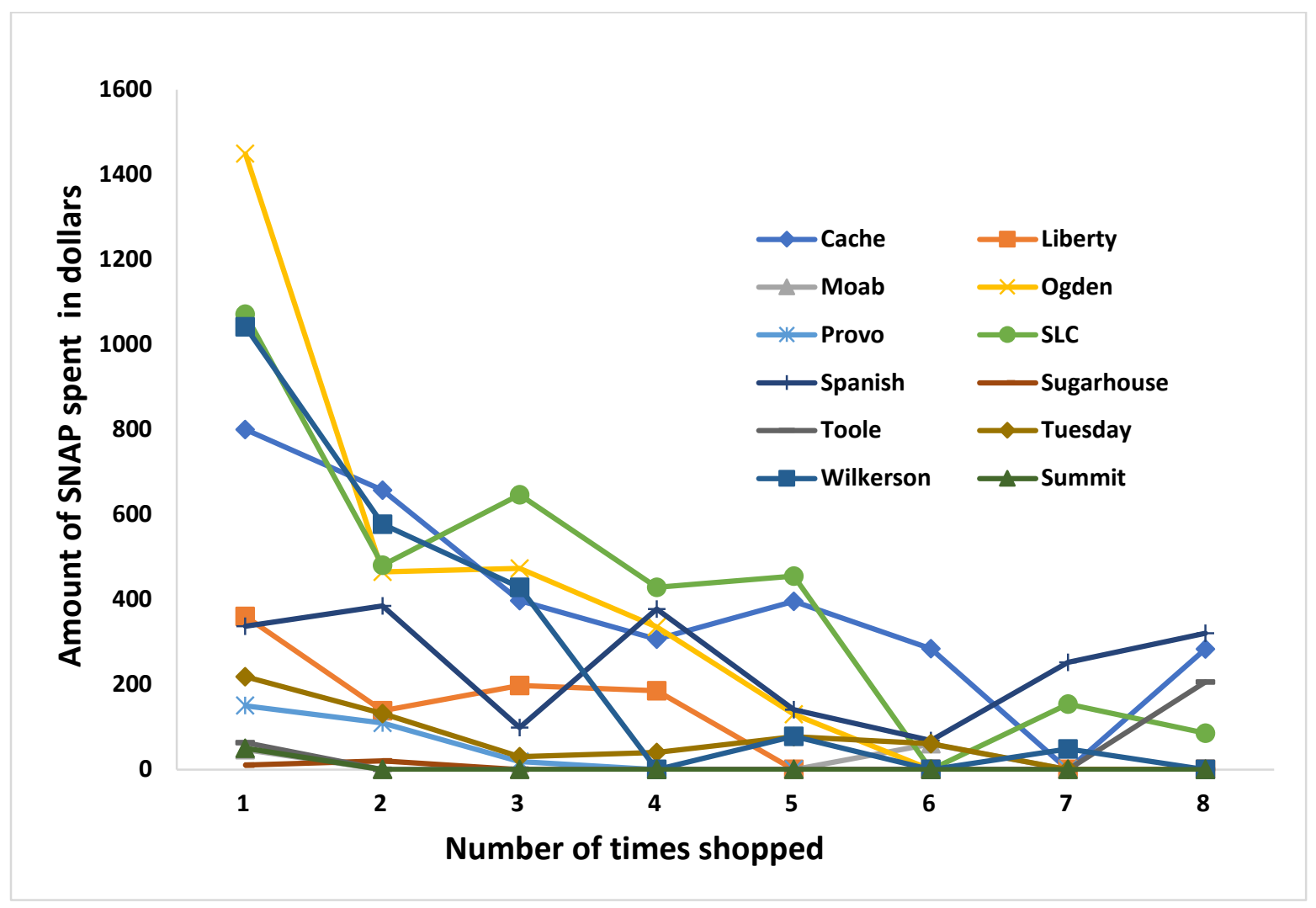

Multiple Market Shopping

Out of 562 tracked unique DUFB users, there were only 13 (2.3\%) who shopped at multiple markets. These shoppers were responsible for $50(4.8 \%)$ of the tracked transactions. Multiple market shoppers made transactions across markets a maximum of 9 times and a minimum of 2 times, an average of 3.8 times. Multiple-market shoppers visited a maximum of 3 different markets throughout the market season, with most multiple-market shoppers only going to 2 markets. Wilkerson has the highest number of multiple market shoppers $(\mathrm{n}=8)$ and 3 markets (Tooele, Moab, and Summit) had no multiple market shoppers. 
Figure 5. Number of Multiple Market Shoppers between Markets

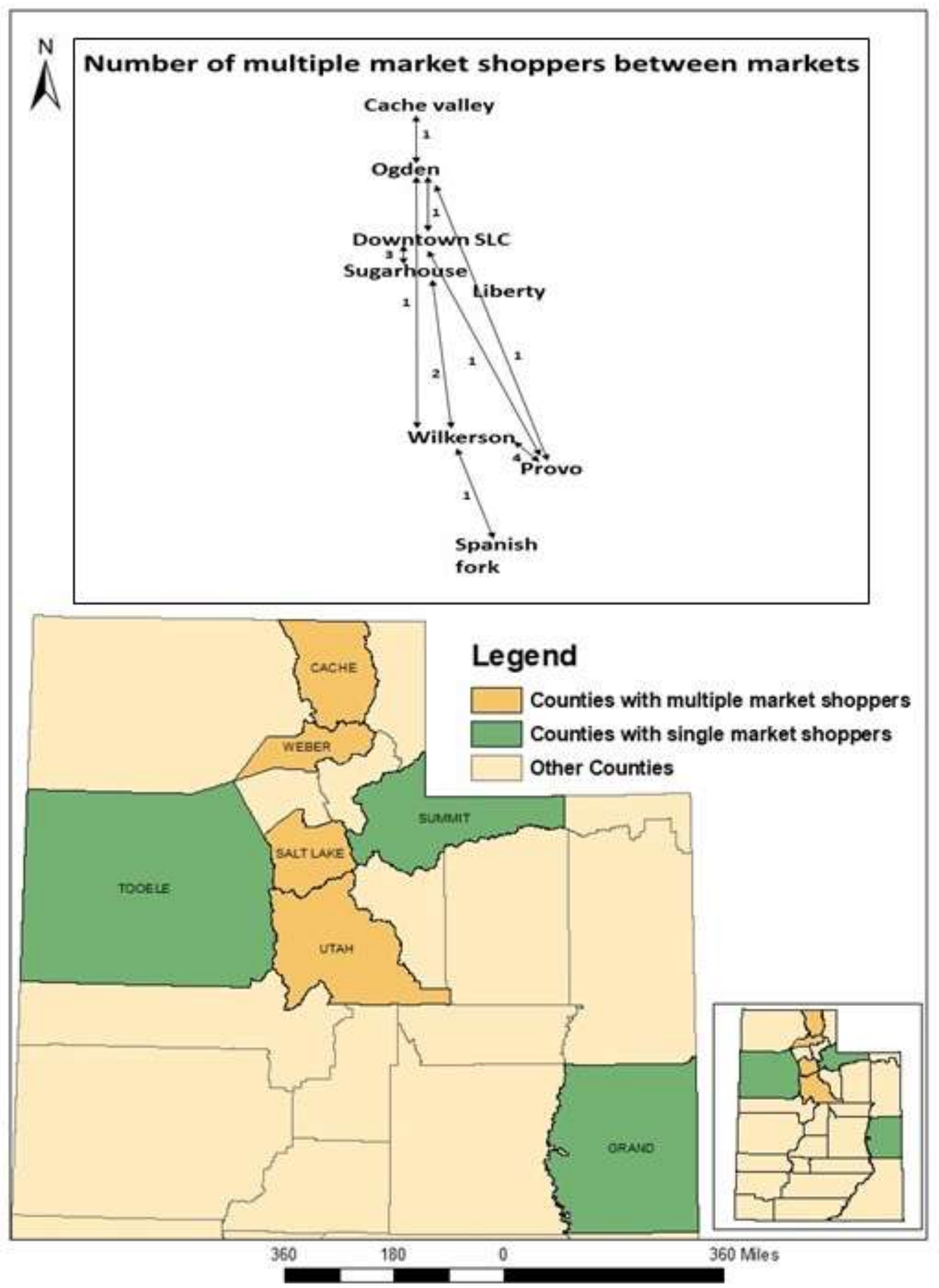




\section{Conclusion}

With the way the DUFB program is currently designed, frequent visits to the FM may likely increase the use of and the amount of DUFB benefits that the program participants can access. Therefore, it is important to encourage frequent use among SNAP recipients to improve access to reduced-cost fruits and vegetables. However, encouraging program usage among all types of shoppers (more and less frequent shoppers, multiple markets, and single market shoppers) contributes to the total SNAP revenue for the markets.

\section{Recommendations for Policy, Practice, and Research}

Previous studies have established evidence that SNAP recipients face various barriers (lack of transportation, lack of awareness, inconvenient time, location of operation, etc.) in their ability to access farmer's market incentive programs (Freedman et al., 2016; Nuss, Skizim, Afaneh, Miele, \& Sothern, 2017; Olsho et al., 2015; Savoie-Roskos et al., 2016;). These potential limitations indicate that not all SNAP recipients may be able to make frequent FM trips that could in turn improve their access to healthier food options. Nutrition programs that would help increase awareness of the DUFB program's benefits among SNAP recipients especially at the FM outlets might encourage frequent visits. Further, strategies that could encourage frequent visits among FM shoppers may be set in place in individual markets during the FM season e.g. coupons, refera-friend and points accumulation per visit to redeem later etc. Moreover, unless the different barriers to healthy food access are addressed, frequent use of the incentive program among the intended population might not be possible. Therefore, policies that would address other barriers such as transportation or expanding the program to vendors that are open for more hours. In addition, a more-detailed and well-monitored tracking system is needed to evaluate communitybased programs like this SNAP-based incentive program. Therefore, future research should examine an effective way to monitor such community-based programs using a tracking system and identify best practices for monitoring and evaluating such programs. Finally, future research using a tracking system should ensure that adequate information is provided for the farmer's market managers and that the data collection process is well monitored. 


\section{Appendix}

\section{Appendix A. Categories of the Different Entries}

\begin{tabular}{|l|c|c|}
\hline Categories & Frequency & $\begin{array}{c}\text { Percentage } \\
(\%)\end{array}$ \\
\hline Numbers within DUFB sticker and market range & 1040 & 66.4 \\
\hline Numbers within DUFB sticker but outside any market range & 110 & 7.0 \\
\hline Numbers that has no replicate in markets within that range & 28 & 1.8 \\
\hline $\begin{array}{l}\text { Numbers occurring in multiple markets but date of first use does not align } \\
\text { with market first issued that range }\end{array}$ & 2 & 0.1 \\
\hline Numbers outside DUFB sticker numbers (>3000) & 341 & 21.8 \\
\hline $\begin{array}{l}\text { Numbers that matches Rx number with a different sticker number but not } \\
\text { the same with the similar DUFB sticker number }\end{array}$ & 17 & 1.1 \\
\hline No sticker number recorded & 23 & 1.5 \\
\hline Refused Sticker & 3 & 0.2 \\
\hline Numbers from outside Utah State & 3 & 0.2 \\
\hline
\end{tabular}




\section{Appendix B. Sticker Record-keeping and Entries Associated with a Unique Individual Sticker (Tracked) across the Different Markets}

\begin{tabular}{|c|c|c|c|c|c|c|c|c|c|c|c|}
\hline Markets & $\begin{array}{l}\text { Sticker- } \\
\text { tracked } \\
\text { DUFB } \\
\text { Entries }\end{array}$ & $\begin{array}{l}\text { Excluded } \\
\text { DUFB } \\
\text { Entries }\end{array}$ & $\begin{array}{l}\text { Total } \\
\text { Entries }\end{array}$ & $\begin{array}{l}\text { Tracked } \\
\text { Unique } \\
\text { Individuals }\end{array}$ & $\begin{array}{l}\text { Total } \\
\text { amount } \\
\text { of } \\
\text { SNAP } \\
(\$)\end{array}$ & $\begin{array}{l}\text { Total } \\
\text { DUFB } \\
\text { amount } \\
\text { of } \\
\text { (Token) }\end{array}$ & $\begin{array}{l}\text { Tracked } \\
\text { amount } \\
\text { of SNAP } \\
(\$)\end{array}$ & $\begin{array}{l}\text { Tracked } \\
\text { amount } \\
\text { of DUFB } \\
\text { (Token) }\end{array}$ & $\begin{array}{l}\% \\
\text { Tracked } \\
\text { SNAP }\end{array}$ & $\begin{array}{l}\% \text { of } \\
\text { Tracked } \\
\text { DUFB } \\
\text { Token }\end{array}$ & $\begin{array}{l}\text { Tracked } \\
\text { DUFB Vs } \\
\text { Total SNAP } \\
\text { Transactions } \\
(\%)\end{array}$ \\
\hline Benson Grist Mill & 0 & 26 & 26 & 0 & 371 & 234 & 0 & 0 & 0 & 0 & 0 \\
\hline Brigham City & 0 & 23 & 23 & 0 & 441 & 164 & 0 & 0 & 0 & o & 0 \\
\hline Syracuse & 0 & 13 & 13 & 0 & 108.5 & 105.5 & 0 & 0 & 0 & 0 & 0 \\
\hline $\begin{array}{l}\text { Sugar House Farmers } \\
\text { Market }\end{array}$ & 3 & 40 & 43 & 2 & 486 & 376 & 30 & 30 & 6 & 8 & 6 \\
\hline Provo & 24 & 251 & 275 & 17 & 3415 & 2546 & 277 & 228 & 8 & 9 & 7 \\
\hline Moab & 12 & 16 & 28 & 7 & 296 & 116 & 106 & 106 & 36 & 91 & 36 \\
\hline Tooele Valley Nursery & 13 & 2 & 15 & 6 & 299 & 138 & 296 & 108 & 99 & 78 & 36 \\
\hline Spanish Fork & 97 & 19 & 116 & 40 & 2247 & 973 & 1977 & 830 & 88 & 85 & 37 \\
\hline $\begin{array}{l}\text { SLC Downtown Farmers } \\
\text { Market }\end{array}$ & 235 & 113 & 348 & 122 & 5141 & 3138 & 3319 & 2169 & 65 & 69 & 42 \\
\hline $\begin{array}{l}\text { Summit County Community } \\
\text { Market }\end{array}$ & 5 & 0 & 5 & 5 & 50 & 50 & 50 & 50 & 100 & 100 & 46 \\
\hline Liberty Park & 48 & 2 & 50 & 34 & 900 & 450 & 880 & 430 & 98 & 96 & 48 \\
\hline Wilkerson & 138 & 9 & 147 & 92 & 2278.91 & 1167 & 2172.11 & 1113 & 95 & 95 & 49 \\
\hline $\begin{array}{l}\text { Cache Valley Gardeners } \\
\text { Market }\end{array}$ & 217 & 5 & 222 & 104 & 3174 & 2090 & 3122 & 2050 & 98 & 98 & 65 \\
\hline Ogden & 200 & 4 & 204 & 136 & 2882 & 1917 & 2852 & 1887 & 99 & 98 & 65 \\
\hline Tuesday Farmers Market & 48 & 4 & 52 & 27 & 609 & 478 & 556 & 440 & 91 & 92 & 72 \\
\hline
\end{tabular}


Appendix C: Total DUFB per Market Versus Tracked DUFB Users

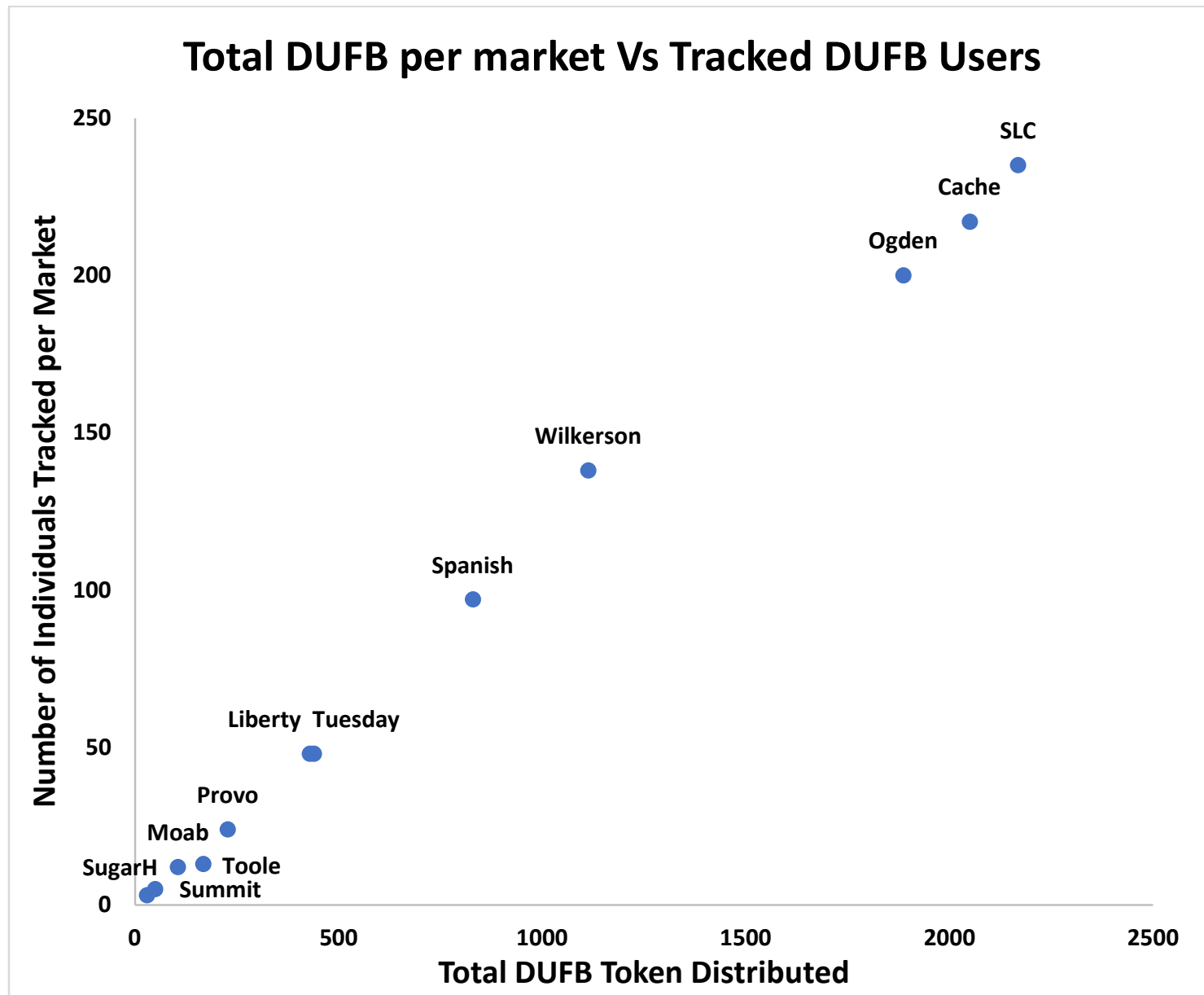

Appendix D: Frequency Of Farmer's Market Visit Versus Number of Individuals

\begin{tabular}{|r|r|}
\hline $\begin{array}{l}\text { Frequency of } \\
\text { Visits }\end{array}$ & Numbers of Individual \\
\hline 1 & 365 \\
\hline 2 & 95 \\
\hline 3 & 60 \\
\hline 4 & 31 \\
\hline 5 & 16 \\
\hline 6 & 12 \\
\hline 7 & 5 \\
\hline 8 & 5 \\
\hline 9 & 1 \\
\hline 12 & 1 \\
\hline 14 & 1 \\
\hline
\end{tabular}


Appendix E: Number of Weeks of DUFB Possible and Recorded Per Market

\begin{tabular}{|c|c|c|c|c|c|c|}
\hline Market & $\begin{array}{l}\text { Number } \\
\text { of } \\
\text { weeks } \\
\text { in the } \\
\text { records }\end{array}$ & $\begin{array}{l}\text { Number } \\
\text { of weeks } \\
\text { between } \\
\text { start } \\
\text { date and } \\
\text { end date } \\
\text { recorded }\end{array}$ & $\begin{array}{l}\text { Operation } \\
\text { days }\end{array}$ & $\begin{array}{l}\text { First } \\
\text { day on } \\
\text { record }\end{array}$ & $\begin{array}{l}\text { Last } \\
\text { day }\end{array}$ & Note \\
\hline $\begin{array}{l}\text { Benson Grist } \\
\text { Mill }\end{array}$ & 10 & 9 & Saturdays & $\begin{array}{l}\text { th } \\
\text { Aug }\end{array}$ & $\begin{array}{l}\text { 29th } \\
\text { Sept }\end{array}$ & $\begin{array}{l}\text { We have a record for 6th } \\
\text { Sept, which is not a } \\
\text { Saturday but a Thursday }\end{array}$ \\
\hline Brigham City & 6 & 7 & Saturdays & $\begin{array}{l}\text { 11th } \\
\text { Aug }\end{array}$ & $\begin{array}{l}\text { 22th } \\
\text { Sept }\end{array}$ & $\begin{array}{l}\text { missing record for } 8 \text { th } \\
\text { Sept }\end{array}$ \\
\hline $\begin{array}{l}\text { Cache Valley } \\
\text { Gardeners } \\
\text { Market }\end{array}$ & 11 & 12 & Saturdays & $\begin{array}{l}\text { 4th } \\
\text { Aug }\end{array}$ & 20th Oct & Missing 6th Oct \\
\hline Liberty Park & 10 & 10 & $\begin{array}{l}\text { Friday/ } \\
\text { Saturdays }\end{array}$ & $\begin{array}{l}\text { 3rd } \\
\text { Aug }\end{array}$ & 6th Oct & \\
\hline Moab & 17 & 22 & Friday & $\begin{array}{l}\text { 4th } \\
\text { May }\end{array}$ & $\begin{array}{l}\text { 28th } \\
\text { Sept }\end{array}$ & $\begin{array}{l}\text { missing May } 18 \mathrm{th}, 25 \text { th, } \\
\text { July } 13 \text { th, Aug } 3 \mathrm{rd}, 10 \text { th }\end{array}$ \\
\hline Ogden & 12 & 13 & Saturdays & $\begin{array}{l}\text { 4th } \\
\text { Aug }\end{array}$ & 27 th Oct & missing Sept 15 th \\
\hline Provo & 15 & 15 & Saturdays & $\begin{array}{l}21 \text { st } \\
\text { July }\end{array}$ & 27 th Oct & \\
\hline $\begin{array}{l}\text { SLC } \\
\text { Downtown } \\
\text { Farmers } \\
\text { Market }\end{array}$ & 10 & 12 & Saturdays & $\begin{array}{l}\text { 4th } \\
\text { Aug }\end{array}$ & 20th Oct & $\begin{array}{l}\text { missing Aug 18th and } \\
25 \text { th }\end{array}$ \\
\hline Spanish Fork & 12 & 13 & Saturdays & $\begin{array}{l}\text { 4th } \\
\text { Aug }\end{array}$ & 27 th Oct & missing Sept 15th \\
\hline $\begin{array}{l}\text { Sugar House } \\
\text { Farmers } \\
\text { Market }\end{array}$ & 11 & 12 & Wednesday & $\begin{array}{l}\text { 11th } \\
\text { July }\end{array}$ & $\begin{array}{l}\text { 26th } \\
\text { Sept }\end{array}$ & missing July 18 th \\
\hline $\begin{array}{l}\text { Summit } \\
\text { County }\end{array}$ & 2 & 5 & Tuesdays & $\begin{array}{l}14 \text { th } \\
\text { Aug }\end{array}$ & $\begin{array}{l}\text { 11th } \\
\text { Sept }\end{array}$ & $\begin{array}{l}\text { missing Aug 21th, 28th, } \\
\text { and Sept } 4^{\text {th }}\end{array}$ \\
\hline
\end{tabular}




\begin{tabular}{|l|l|l|l|l|l|l|}
\hline $\begin{array}{l}\text { Community } \\
\text { Market }\end{array}$ & & & & & \\
\hline Syracuse & 6 & 8 & Wednesday & $\begin{array}{l}\text { 11th } \\
\text { July }\end{array}$ & $\begin{array}{l}\text { 29th } \\
\text { Aug }\end{array}$ & $\begin{array}{l}\text { missing July 25th, Aug } \\
1 \text { st }\end{array}$ \\
\hline $\begin{array}{l}\text { Tooele Valley } \\
\text { Nursery }\end{array}$ & 9 & 9 & Saturdays & $\begin{array}{l}\text { 4th } \\
\text { Aug }\end{array}$ & $\begin{array}{l}\text { 29th } \\
\text { Sept }\end{array}$ & \\
\hline $\begin{array}{l}\text { Tuesday } \\
\text { Farmers } \\
\text { Market }\end{array}$ & 8 & 8 & Tuesdays & $\begin{array}{l}\text { 7th } \\
\text { Aug }\end{array}$ & $\begin{array}{l}\text { 25th } \\
\text { Sept }\end{array}$ & \\
\hline Wilkerson & 14 & 14 & Everyday & 1st Aug & 29th Oct & \\
\hline
\end{tabular}




\section{References}

Alaofè, H., Freed, N., Jones, K., Plano, A., \& Taren, D. (2017). Impacts of Double Up SNAP Farmers' Market Incentive Program on Fruit and Vegetable Access, Purchase and Consumption. Journal of Nutrition and Health Sciences, 4(3). https://doi.org/10.15744/2393-9060.4.304

Durward, C. M., Savoie-Roskos, M., Atoloye, A., Isabella, P., Jewkes, M. D., Ralls, B., ... LeBlanc, H. (2018). Double Up Food Bucks Participation is Associated with Increased Fruit and Vegetable Consumption and Food Security Among Low-Income Adults. Journal of Nutrition Education and Behavior. https://doi.org/10.1016/j.jneb.2018.08.011

Freedman, D. A., Vaudrin, N., Schneider, C., Trapl, E., Ohri-Vachaspati, P., Taggart, M., ... Flocke, S. (2016). Systematic Review of Factors Influencing Farmers' Market Use Overall and among Low-Income Populations. Journal of the Academy of Nutrition and Dietetics, 116(7), 1136-1155. https://doi.org/10.1016/j.jand.2016.02.010

Nuss, H., Skizim, M., Afaneh, H., Miele, L., \& Sothern, M. (2017). Farmers' Market Utilization among Supplemental Nutrition Assistance Program Recipients in New Orleans, Louisiana: Preliminary Findings. Ethnicity \& Disease, 27(Suppl 1), 295-302. https://doi.org/10.18865/ed.27.S1.295

Olsho, L. E., Payne, G. H., Walker, D. K., Baronberg, S., Jernigan, J., \& Abrami, A. (2015). Impacts of a farmers' market incentive programme on fruit and vegetable access, purchase and consumption. Public Health Nutrition, 18(15), 2712-2721. https://doi.org/10.1017/S1368980015001056

Savoie-Roskos, M., Durward, C., Jeweks, M., \& LeBlanc, H. (2016). Reducing Food Insecurity and Improving Fruit and Vegetable Intake Among Farmers' Market Incentive Program Participants. Journal of Nutrition Education and Behavior, 48(1), 70-76.e1. https://doi.org/10.1016/j.jneb.2015.10.003 